DOI: $10.17951 /$ lrp.2018.37.3.257-266

\author{
LILIYA MORSKA \\ Ivan Franko National University of Lviv; \\ The University of Bielsko-Biała \\ https://orcid.org/0000-0002-4916-3834
}

\title{
EDUCATIONAL VALUES: CURRENT VIEWS AND PERSPECTIVES FOR MODERN SCHOOL
}

\begin{abstract}
The article presents the author's viewpoint on the value-rich education and its possible development in modern schooling society. The notions of "values" and "educational values" have been discussed. On the basis of the discussion, the author's understanding of educational values has been suggested. The issue of selection of values to be integrated into school practice has been discussed. As a result, three groups of values that should be placed at the centre of school policy and then integrated into action in the classroom practice have been singled out: 1) foundation values which help a person to gain some orientation in the sense of social responsibility (safety, support, self-control, honesty, considerate and responsible attitude to people and educational activity), 2) focus values, those which enable a person to build relationships with the community and around him/herself (collaboration, confidence, communication, achievement, fallibility, quality, enquiry, play, initiative, wonder, etc.), 3) aspirational values which are based on a person's global responsibility for him/herself, the other people and physical world around (wisdom, holistic approach, membership, knowledge, democratic existence). The framework of educational procedures for integration of the selected values has been created and substantiated in the paper.
\end{abstract}

Keywords: values-rich education, educational values, moral values, modern school, classroom practice, value integration framework

Nowadays, no one seems to doubt that values play a central role not only for the theory of education, but for its practical activities as well. That is because schools and teachers reflect the values of society which are transmitted to schoolchildren and university students. Moreover, educational institutions, together with parents, the media and peers, are a strong influence on the establishment and development of values of children and young people. 
From the theoretical perspective, it is important to mention that values do not tend to be unchanging. It is the role of education to help the schoolchildren and university students define the proper values which will help them to lead a successful and morally appropriate life after they graduate. We should admit that it is not an easy task, because within our society there appear to be some groups (parents, employers, local communities, country leaders, etc.) claiming to establish such values, but a close study of those groups suggests that within each of these groups there is a wide diversity of political, social, economic, religious, ideological and cultural values.

Thus, the goal of the given paper is to develop an algorithm, certain framework for educators, helping them to lead the students on the way of proper analysis and choice of virtuous values in the modern society.

P. Jackson, R. Boostrom and D. Hansen point out that educational values can be introduced even by classroom management procedures and study organization. Students learn the system of values when teachers insist on "precision and accuracy in students' work, or praise their use of imagination, or encourage them to show initiative, or respond with interest, patience or frustration to their ideas" (Jackson, Boostrom, Hansen 1998, p. 19).

It may be true to say that values are something that is "taken for granted" by teachers and students, but then the question arises: why are those values often neglected by both parties, causing a lot of misunderstanding, conflicts and negative outcome of education and educational experience? The answer to this question may be the following: very often it is really difficult to articulate or explore values, they are also impossible to be measured or graded. Another answer might be because teachers are not prepared for reflection on values. Teachers often believe that students should possess the so-called moral instinct, thus values should be "ready for use" the same day as a student enters an educational institution.

There is one more misconception about the investigated issue. Educators believe too much in the power of statements concerning values. For example, even when there is a statement about the value of being treated with respect, not every person will share similar viewpoint concerning what kind of value it is, and what it really means for a student to be treated with respect by a teacher, or vice versa. Moreover, there is often a big difference between what is stated and what is really practised in the educational process.

As a result, many values stay lost or thrown to the domain of hidden school curriculum. This leads to a non-systemic view of values in education, and if there is no systematic discussion of values and value issues with students, they (the values) will probably be developed chaotically (Lovat, Toomey 2009, p. 3). The above-mentioned factors suggest a need for schools to reflect on and voice their values with greater precision (McLaughlin 2005, p. 307). 
To implement clear-cut strategies of value-rich education policy, it seems necessary to solve a number of tasks, some of which might be the following:

- to define whether particular values are valid only within particular social groups, cultures or traditions;

- to find and articulate some overarching principles by which the conflicting values may be united and consoled;

- to decide whether there should be the basis of shared values in our society which will create the common framework for education, or there should be a choice for parents to make concerning the schools with various value grounds;

- to define whether there are some absolute values and decide which values should be considered as such;

- to define the task of teachers in teaching absolute and traditional values, as well as in helping students to explore and develop their own ones.

These and other tasks make up a huge bulk of educational policy in establishing value-rich educational atmosphere in secondary schools and universities. In the paragraphs that follow, we are going to briefly outline the main steps to be taken to gradually complete the above-mentioned tasks. To begin the study, it is necessary to clearly define the key notions.

Values are believed to be the "things that have an intrinsic worth in usefulness or importance to the possessor", or "principles, standards, or qualities considered worthwhile or desirable" (Human Values - Role of Family, Society...), thus constituting and extremely significant aspect of self-concept of any individual and serving as guiding principles in his or her daily activities, and life in general. In school, for example, such values are established in its organization, discipline procedures, curriculum, the relationship between teachers and students, and their parents. We can see the reflection of school values in what teachers allow students to do, in what they encourage students to achieve, in the pattern of students' behavior that is most welcome by teachers. Such values are also reflected in teachers' response to students' achievements in learning and building up relationships with peers and other members of their school society.

Some of the studies see values as "things" which are considered "good" in themselves (such as beauty, truth, love, honesty and loyalty) and as personal or social preferences (Barker, Halman, Vloet 1992, p. 19). L. Raths, M. Harmin and S. Simon (1966, p. 28) describe values as "beliefs, attitudes or feelings that an individual is proud of, is willing to publicly affirm; (...) a value is something that has been chosen thoughtfully from alternatives without persuation, and is acted on repeatedly". Such a definition is, on the one hand, quite a detailed one though, and on the other hand, a descriptive character of this definition makes it 
quite difficult to clearly outline the boundaries of values in a person's behaviour or activity in any sphere of life.

J.R. Fraenkel (1988, p. 11) considers values as being "both emotional commitments and ideas about worth". In this definition, again, values appear to be quite temporary, like preferences taken into account under particular situation, since emotional commitment seems to be quite changeable depending on the circumstances that trigger certain emotional condition of a person.

A more recent study of values considers them to be

(...) the principles, fundamental convictions, ideals, standards or life stances which act as general guides to behaviour or as points of reference in decision-making or the evaluation of beliefs or actions and which are closely connected to personal integrity and personal identity (Halstead, Taylor 2005, p. 12).

Such a definition seems quite completing, though it combines rather broad notions which, in turn, need further explanation and interpretation, and, thus, make the understanding of the primary term - that of "values" - quite complicated. Moreover, its authors accept the fact that their definition is open to criticism stating that it "fails to differentiate quite distinct things like virtues, convictions and commitments, and that it treats values as a kind of possession, something which people have" (Halstead, Taylor 2005, p. 12). Though, we would claim that the latter idea may be considered as a positive one rather than a negative, as viewed by the authors, since values are established, being developed and gain the quality as something obtained, thus becoming a person's developmental achievement, and consequently a possession. Furthermore, once firmly established, such a position can rarely be taken out from its owner. Thanks to such quality, we believe, values become the true guides in further "turbulent" path of an individual's life.

In another study of the recent years (Lovat, Toomey, Clement 2010, p. 21 (xx)), values are believed to be "embodied in our understanding of what it means to be human (...), permeate the pedagogy, are reflected in the ways in which moral responsibility and personal integrity are enhanced, end point to the inclusion, in a broader vision of educational aims, of social engagement and citizenship". The latter interpretation of values brings us very close to a conviction that education and schooling system should urgently consider the significance of value education and take appropriate measures to create the updated model or framework of integration of value education into the whole system of education. As a result, to make the system work, values and value education should be placed at the centre of school policy and classroom practice.

There arises another question: what set of values should take this central position? It is not easy to answer the question, bearing in mind the fact that we 
are teaching young people in a monocultural-globalised society. Though, some scientists have made an attempt to outline the minimum set of common values and standards of behavior. For example, M.J. Halstead and M.J. Taylor (2005, p. 6) suggest that this should include: 1) basic social morality (a respect for justice and a recognition that other groups have as much right as one's own to avoid physical pain and death among their members), 2) the acceptance of a common system of law and government by all groups within the broader society, 3) understanding of the significance that is attached to these common values.

No matter what core values have been chosen to be integrated into the educational system, it is important to highlight the main issues of how to put the values education into practice.

The first step to be taken here is to re-evaluate the role of school and teachers in effecting change in student achievement. Such a role was diminished to some extent, which was quite often reflected in pedagogical research of the recent years (Lovat, Toomey 2009, p. 18). Discarding such pessimism, in our view, could encourage teachers and school to take more responsibility and action in establishing the values system of every student and, thus, build up a society of value-rich citizens, which, in turn, could eliminate a number of problems arising from the lack of value possession.

The above-mentioned statement can be supported with the findings expressed by the Carnegie Report (Lovat, Toomey 2009, p. 20). The Report revolutionised the necessity for values education paradigm to be implemented in modern school, by stretching traditional conceptions of learning and achievement and defining them as a broad array of outcomes. But the most important point of the Report in this respect was singling out such aspects as communicative skills, empathy, reflection and self-management, alongside with intellectual development as the foundational objectives of teaching and schooling. To develop such qualities in students requires a holistic approach to teaching as applied by educators and laid at the foundation of the whole system of education. This, in turn, leads to demanding craft and techniques, modelling and positive relationships established by teachers.

Everything mentioned above proves the fact that values should not be considered as something taken for granted, but there should be a well-thought strategy of "communicating the values", creating values education environment.

We firmly believe that every school should create and then clearly articulate the value-rich culture of the institution. Some of the components of such culture might be the following: student wellbeing policy based on a values and rational model paradigm, but not punishment-based one; accountability which depicts expectations of every individual student and his or her understanding of the necessity of collective responsibility for reaching the goals and achieving outcomes that 
have been planned by a well-thought school strategy; professional development of the staff as a must on the way to improve the learning processes and practices of the school on a larger scale.

Though, the above-mentioned culture sheds some light on the issue of values integration into school practices, there should be developed a model of implementation of such value-rich culture.

C. MacMullin and L. Scalfino (2009, p. 47) suggest three groups of values that should be placed at the centre of school policy and then integrated into action in the classroom practice: 1) foundation values which help a person to gain some orientation in the sense of social responsibility, thus, sketching the outline of ethically-coloured behavior (safety, support, self-control, honesty, considerate and responsible attitude to people and educational activity), 2) focus values, those which enable a person to build relationships with the community and around him/ herself (collaboration, confidence, communication, achievement, fallibility, quality, enquiry, play, initiative, wonder, etc.), 3) aspirational values which are based on a person's global responsibility for him/herself, the other people and physical world around (wisdom, holistic approach, membership, knowledge, democratic existence).

The above-mentioned researchers suggest the vision of how these three value groups could be implemented in the school practice, grouping the values within groups into certain clusters and then extracting core values from the latter, at the same time indicating the steps to be taken by each member of school community in the form of the so-called personal commitment which should result in the action, which, in turn, could be seen or measured. The graphic model of the vision is presented in Figure 1.

To make the vision come true, it is necessary, to our mind, to create a certain model, a framework, within which the values will gain support from other school system components, which, in turn, will allow the members of school community to follow and cherish the school values-rich institutional culture.

In Figure 2, there is a sample of our framework, which we believe is able to draw the attention of the school members (both students and teachers) to values and their importance in the overall success of the school and the educational process. The key components of this framework are the following: application of effective pedagogies and technologies, which will improve students' learning and foster their well-being, and then the students will feel engaged in the life of the school community. These components serve as the core issues of the framework concept, but the other cornerstones should be taken into account as well; moreover, such aspects as accountability, contextual influences, authentic leadership and school strategy vision should be interconnected and implemented (Figure 2). 

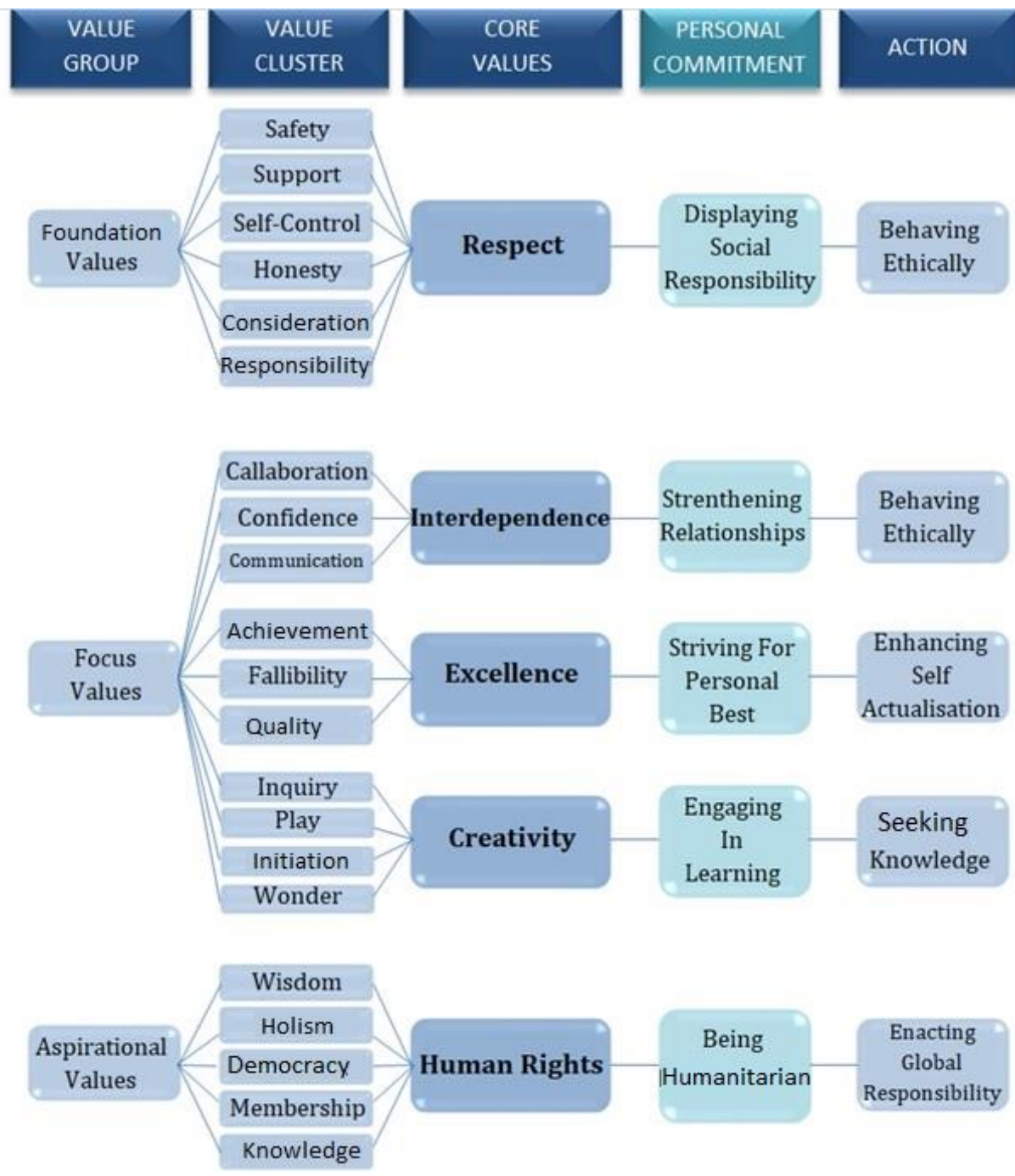

Figure 1. Education values

Source: Author's own study.

Apart from the core issues and the framework cornerstones, every student at the value-rich school should realise the necessity of: 1) self-knowledge, thus taking a deep insight into the goals and intrinsic motivation triggers, 2) world views and beliefs, since lies in the globalised world demand such knowledge and competences, 3) being inquisitive, since any knowledge and competencies do not 
fall from the sky, and cannot be taken as something ready-for-use; on the contrary, they should be developed by means of the culture of inquiry, 4) action, since only by applying the action-based approach, theory is possible to come into practice, and prove its effectiveness.

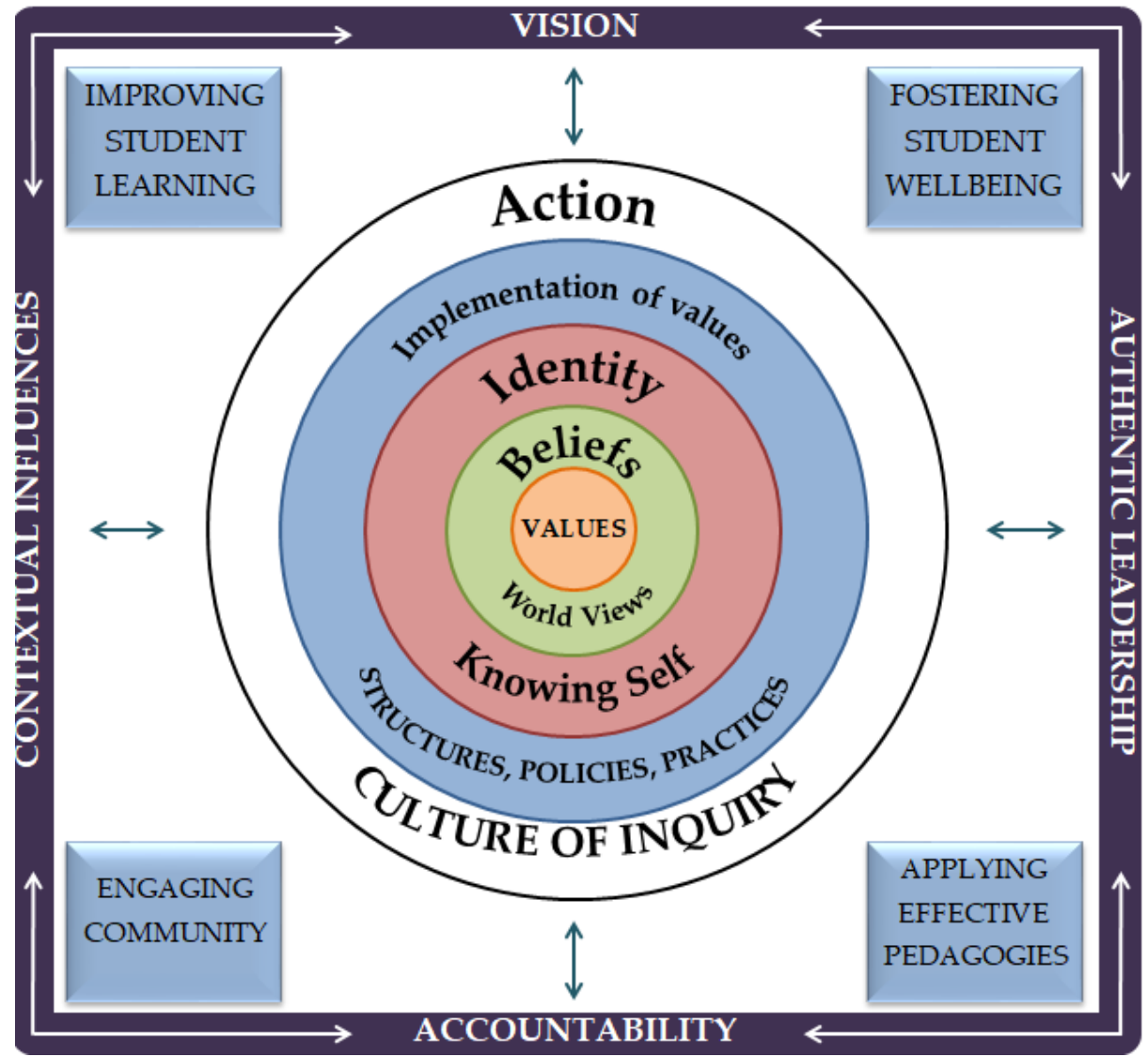

Figure 2. Values integration into school practice

Source: Author's own study.

In summary, we have proven that modern school and educational system in general feel a great need for changes, but the changes of the form or the content of learning (which have taken place in a number of educational reforms in certain countries for the past 10 or so years) bring some positive effect, though such a situation seems to be very temporary. More decent effects arise from reforms based on the change of "the mind and soul" of the educational process, which can 
be achieved by applying values-rich culture practices in school. Such application should be a well-thought and planned process, the model of which has been suggested and described in the given paper.

We presume that the suggested model or framework might have some inaccuracies, or maybe even drawbacks. Thus, we feel the need to test its efficiency by integrating it into the educational process of certain Ukrainian schools. The result of such testing will be presented in our future papers.

\section{REFERENCES}

Barker, D., Halman, L., Vloet, A., 1992, The European Values Study, 1981-1990. Aberdeen: Gordon Cook Foundation on behalf of the European Values Group. Fraenkel, J.R., 1988, How To Teach about Values: An Analytical Approach. Englewood Cliffs, NJ: Prentice Hall.

Human Values - Role of Family, Society and Educational Institutions in Inculcating Values (GS Paper 4), https://selfstudyhistory.com/2015/09/13/human-values-roleof-family-society-and-educational-institutions-in-inculcating-values-gs-paper-4/ [access: 03.04.2017].

Jackson, P.W., Boostrom, R.E., Hansen, D.T., 1998, The Moral Life of Schools. San Francisco: Jossey-Bass.

Lovat, T., Toomey, R., Clement, N., 2010, International Research Handbook on Values Education and Student Wellbeing. Dordrecht-Heidelberg-London-New York: Springer Science+Business Media B.V.

MacMullin, C., Scalfino, L., 2009, Placing values at the centre of school policy and classroom practice - a case study of Modbury School, South Australia. In: T. Lovat, R. Toomey (eds.), Values Education and Quality Teaching: The Double Helix Effect. Dordrecht: Springer Science+Business Media B.V., pp. 45-54.

McLaughlin, T., 2005, The educative importance of ethos. "British Journal of Educational Studies", vol. 53 (3), pp. 306-325.

Raths, L.E., Harmin, M., Simon, S.B., 1966, Values and Teaching: Working with Values in the Classroom. Columbus, OH: Charles E. Merrill.

Values Education and Quality Teaching: The Double Helix Effect, 2009, T. Lovat, R. Toomey (eds.), Dordrecht: Springer Science+Business Media B.V.

Values in Education and Education in Values, 2005, M.J. Halstead, M.J. Taylor (eds.), London: The Falmer Press. 


\title{
WARTOŚCI EDUKACYJNE: POTOCZNE POGLĄDY I PERSPEKTYWY DLA WSPÓŁCZESNEJ SZKOŁY
}

\begin{abstract}
Abstrakt: W opracowaniu zaprezentowano punkt widzenia autorki na bogatą w wartości edukację oraz szanse jej rozwoju we współczesnym społeczeństwie. W tekście zostały omówione pojęcia: „wartości” i „wartości oświatowe”. Odniesiono się też do wyniku wyboru integralnych w praktyce szkolnej wartości. Wyłoniono trzy grupy wartości, które należy uwzględnić w polityce oświatowej szkoły, a następnie w formie zintegrowanej wdrażać je w praktyce edukacyjnej. Są to: 1) główne wartości o charakterze społecznym (bezpieczeństwo, wsparcie, uczciwość, obowiązkowość, odpowiedzialność itp.), 2) wartości, które pozwalają nawiązać społeczne relacje (współpraca, komunikacja, inicjatywa, empatia, stawianie pytań itp.), 3) wartości ambicjonalne jednostki - odpowiedzialność za siebie i innych (mądrość, wiedza, moralność itp.). Ujęta w strukturze oświatowych procedur integracja wyżej wskazanych wartości została przedstawiona w pracy.
\end{abstract}

Słowa kluczowe: wartości w edukacji, wartości oświatowe, wartości moralne, współczesna szkoła, szkolna praktyka edukacyjna, struktura integracji wartości 